\title{
\begin{tabular}{|l|l|}
\hline PEDIATRIC & PULMONOLOGY \\
\hline
\end{tabular}
}

\section{Age-related changes in childhood wheezing characteristics: a whole population study}

\begin{tabular}{|c|c|}
\hline Journal: & Pediatric Pulmonology \\
\hline Manuscript ID & PPUL-17-0262.R1 \\
\hline Wiley - Manuscript type: & Original Article: Asthma \\
\hline Date Submitted by the Author: & $\mathrm{n} / \mathrm{a}$ \\
\hline Complete List of Authors: & $\begin{array}{l}\text { Jurca, Maja; University of Bern, Institute of Social and Preventive Medicine } \\
\text { Pescatore, Anina; University of Bern, Institute of Social and Preventive } \\
\text { Medicine } \\
\text { Goutaki, Myrofora; University of Bern, Institute of Social and Preventive } \\
\text { Medicine; Children's University Hospital of Bern, Paediatric Respiratory } \\
\text { Medicine } \\
\text { Spycher, Ben; University of Bern, Institute of Social and Preventive } \\
\text { Medicine } \\
\text { Beardsmore, Caroline; University of Leicester, Leicester Royal Infirmary, } \\
\text { Department of Infection, Immunity and Inflammation } \\
\text { Kuehni, Claudia; University of Bern, Institute of Social and Preventive } \\
\text { Medicine; Children's University Hospital of Bern, Paediatric Respiratory } \\
\text { Medicine }\end{array}$ \\
\hline Keywords: & Epidemiology \\
\hline Other Keywords: & prevalence, wheeze, phenotypes, triggers, cohort \\
\hline Abstract: & $\begin{array}{l}\text { BACKGROUND: Wheezing illnesses are characterised by phenotypic } \\
\text { variability, which changes with age, but few studies report on a wide age } \\
\text { range of children. We studied how prevalence, severity, and triggers of } \\
\text { wheeze vary throughout childhood. } \\
\text { METHODS: We analysed data from a large population-based cohort of } \\
\text { children from Leicestershire, UK, who were followed from infancy through } \\
\text { late adolescence using postal questionnaires. We used generalised } \\
\text { estimating equations to describe age-related changes in prevalence of any } \\
\text { wheeze: episodic viral and multiple trigger wheeze; wheeze triggered by } \\
\text { exercise, aeroallergens, food/drinks, laughing/crying; and of severe } \\
\text { wheeze (frequent attacks, shortness of breath, sleep disturbance, } \\
\text { disturbance of daily activities) from age } 1 \text { to } 18 \text { years. We analysed this in } \\
\text { the entire cohort (absolute prevalence) and separately among children with } \\
\text { wheeze (relative prevalence). } \\
\text { RESULTS: This study included } 7,670 \text { children. Current wheeze was most } \\
\text { common in } 1 \text {-year-olds ( } 36 \% \text { ) and then decreased in prevalence to reach } \\
17 \% \text { in children aged } 14-17 \text { years. Absolute prevalence of episodic viral } \\
\text { wheeze (EVW) decreased with age (from } 24 \% \text { to } 7 \% \text { ), while multiple }\end{array}$ \\
\hline
\end{tabular}


2

\section{SCHOLARONE ${ }^{m}$}

trigger wheeze (MTW) remained relatively constant throughout childhood (8-12\%). Among children with wheeze, the proportion with EVW decreased, and the proportion with MTW increased with age. In older children, wheeze triggered by exercise or aeroallergens, and wheeze accompanied by shortness of breath became more frequent, while wheeze triggered by food or laughter, and sleep disturbance decreased in prevalence.

CONCLUSION: Knowledge of these age-related changes in wheezing illness is informative for health care planning and the design of future research projects and questionnaires.

\section{Manuscripts}


1 33. van Wonderen KE, Geskus RB, van Aalderen WM, Mohrs J, Bindels PJ, van der Mark LB, et

2 al. Stability and predictiveness of multiple trigger and episodic viral wheeze in preschoolers. Clin Exp Allergy. 2016;46(6):837-847.

34. Spycher BD, Cochrane C, Granell R, Sterne J, Silverman M, Pedersen E, et al. Temporal stability of multiple trigger and episodic viral wheeze in early childhood. Eur Respir J. 2017; In press.

35. Kurukulaaratchy RJ, Karmaus W, Raza A, Matthews S, Roberts G, Arshad SH. The influence of gender and atopy on the natural history of rhinitis in the first 18 years of life. Clin Exp Allergy. 2011;41(6):851-859.

36. Nissen SP, Kjaer HF, Host A, Nielsen J, Halken S. The natural course of sensitization and allergic diseases from childhood to adulthood. Pediatr Allergy Immunol. 2013;24(6):549-555.

37. Sarafino EP, Paterson ME, Murphy EL. Age and the impacts of triggers in childhood asthma. J Asthma. 1998;35(2):213-217.

38. von Mutius E, Fritzsch C, Weiland SK, Roll G, Magnussen H. Prevalence of asthma and allergic disorders among children in united Germany: a descriptive comparison. BMJ. $1992 ; 305(6866): 1395-1399$.

39. Leonardi NA, Spycher BD, Strippoli MP, Frey U, Silverman M, Kuehni CE. Validation of the Asthma Predictive Index and comparison with simpler clinical prediction rules. J Allergy Clin Immunol. 2011;127(6):1466-1472.e1466.

40. Timonen KL, Pekkanen J, Korppi M, Vahteristo M, Salonen RO. Prevalence and characteristics of children with chronic respiratory symptoms in eastern Finland. Eur Respir J. 1995;8(7):1155-1160. 


\title{
Age-related changes in childhood wheezing characteristics: a whole population study
}

Maja Jurca, $\mathrm{MD}^{1 *}$, Anina M. Pescatore, $\mathrm{PhD}^{1}$, Myrofora Goutaki, MD-PhD ${ }^{1,2}, \mathrm{PD}$. Ben D. Spycher ${ }^{1}$, Caroline S. Beardsmore, $\mathrm{PhD}^{3}$, Prof. Claudia E. Kuehni ${ }^{1,2}$

\section{Affiliations:}

${ }^{1}$ Institute of Social and Preventive Medicine, University of Bern, Bern, Switzerland (the institution where research was primarily done);

2 Paediatric Respiratory Medicine, Children's University Hospital of Bern, Bern, Switzerland;

${ }^{3}$ Department of Infection, Immunity and Inflammation, University of Leicester, Leicester, United Kingdom

* Both authors have contributed equally to the manuscript

\section{Correspondence to:}

Prof. Claudia Kuehni, Institute of Social and Preventive Medicine

Finkenhubelweg 11, CH-3012 Bern, Switzerland;

Tel.: +41 (0)31 63135 07; Fax +41 (0)31 63135 02;

E-mail: claudia.kuehni@ispm.unibe.ch

Funding Source: All phases of this study were supported by the Swiss National Science Foundation (grants: 32003B_162820, PDFMP3-137033, PDFMP3-123162, PZ00P3_147987) and Asthma UK 07/048.

Financial Disclosure: CE Kuehni has received grants by the Swiss National Science Foundation (32003B_162820, PDFMP3-137033, PDFMP3-123162). BD Spycher was supported by a Swiss National Science Foundation fellowship (PZ00P3_147987). CS Beardsmore was in the receipt of grant 07/048 from Asthma UK.

Conflict of Interest: None of the authors has a conflict of interest to disclose.

Key Words: wheeze, phenotypes, triggers, epidemiology, cohort

\begin{abstract}
Abbreviations:
ISAAC- The International Study of Asthma and Allergies in Childhood; EVW- Episodic Viral Wheeze; MTW- Multiple Trigger Wheeze
\end{abstract}

\begin{abstract}
Abbreviated title: Age-related changes in childhood wheezing illness
\end{abstract}




\section{Contributor's Statement:}

Maja Jurca: Ms. Jurca performed the final statistical analyses, wrote and finalised the manuscript, approved the final manuscript as submitted;

Anina M. Pescatore: Dr. Pescatore conceptualised and designed the study, performed the initial statistical analyses, drafted initial manuscript, approved the final manuscript as submitted;

Myrofora Goutaki: Dr. Goutaki supported with input for interpretation of data, reviewed and revised the manuscript, approved the final manuscript as submitted;

Ben D. Spycher: Dr. Spycher supported the statistical analyses, reviewed and revised the manuscript, approved the final manuscript as submitted;

Caroline S. Beardsmore: Dr. Beardsmore supervised data collection, reviewed the manuscript, approved the final manuscript as submitted;

Claudia E. Kuehni: Prof. Kuehni conceptualised and designed the study, collected data, contributed to analysis and interpretation of results, critically reviewed and revised the manuscript, approved the final manuscript as submitted.

All authors agree to be accountable for all aspects of the work in ensuring that questions related to the accuracy or integrity of any part of the work are appropriately investigated and resolved. 


\begin{abstract}
BACKGROUND: Wheezing illnesses are characterised by phenotypic variability, which changes with age, but few studies report on a wide age range of children. We studied how prevalence, severity, and triggers of wheeze vary throughout childhood.

METHODS: We analysed data from a large population-based cohort of children from Leicestershire, UK, who were followed from infancy through late adolescence using postal questionnaires. We used generalised estimating equations to describe age-related changes in prevalence of any wheeze: episodic viral and multiple trigger wheeze; wheeze triggered by exercise, aeroallergens, food/drinks, laughing/crying; and of severe wheeze (frequent attacks, shortness of breath, sleep disturbance, disturbance of daily activities) from age 1 to 18 years. We analysed this in the entire cohort (absolute prevalence) and separately among children with wheeze (relative prevalence).
\end{abstract}

RESULTS: This study included 7,670 children. Current wheeze was most common in 1-yearolds (36\%) and then decreased in prevalence to reach $17 \%$ in children aged $14-17$ years. Absolute prevalence of episodic viral wheeze (EVW) decreased with age (from $24 \%$ to $7 \%$ ), while multiple trigger wheeze (MTW) remained relatively constant throughout childhood (812\%). Among children with wheeze, the proportion with EVW decreased, and the proportion with MTW increased with age. In older children, wheeze triggered by exercise or aeroallergens, and wheeze accompanied by shortness of breath became more frequent, while wheeze triggered by food or laughter, and sleep disturbance decreased in prevalence.

CONCLUSION: Knowledge of these age-related changes in wheezing illness is informative for health care planning and the design of future research projects and questionnaires. 


\section{INTRODUCTION}

The clinical characteristics of wheezing illness in children are variable and change with age. ${ }^{1-4}$ Some children wheeze only during respiratory infections, a phenotype called episodic viral wheeze $(\mathrm{EVW}){ }^{5}$ Other children wheeze without having infections and their episodes can be triggered by different factors. The wheezing in these children is commonly called multiple trigger wheeze (MTW). ${ }^{5,6}$ Trigger factors for MTW include physical exercise, ${ }^{3,7-9}$ other activities associated with increased breathing effort (laughing or crying), contact with aeroallergens ${ }^{7,10,11}$ (such as pollen, house dust, or pets), and ingestion of certain food or drink items, ${ }^{7}$ which lead to wheeze through varying mechanisms (including but not restricted to allergies). Severity of wheezing illness has been described in terms of frequency of episodes, 3 , $7,8,12$ and of severity of episodes measured as sleep disturbance, ${ }^{3,9}$ limitation of daily activities, or association with shortness of breath. ${ }^{9,12}$

From clinical experience, we know that absolute and relative frequency of phenotypes of wheeze, severity indicators, and trigger factors vary depending on the age of children. However, this has not been well quantified. Most studies have focused on one or two age groups, typically on schoolchildren who are 6-7 and 13-14 years old, as in the International Study on Asthma and Allergies in Childhood (ISAAC), ${ }^{3,13}$ or, less often, preschool children. ${ }^{12,14-16}$ No study to our knowledge has shown the change in the clinical picture of wheezing illness from the first years of life throughout childhood. This paper describes prevalence of wheezing illness during the entirety of childhood, from age 1 to 18 years, in a population-based cohort. We assessed the absolute prevalence (as a proportion of all children) and the relative prevalence (as a proportion of children with current wheeze) of a) the phenotypes EVW and MTW, b) wheeze induced by individual triggers, and c) severity indicators. Absolute prevalence reflects the public health perspective (how many children in 
the general population have this type of disease), and relative prevalence describes the perspective of a physician (what proportion of the children visiting for wheeze has this type of disease).

1

2

3

4

5

6

10

11

12

13

14

15

16

17

18

19

20

21

22

23

24

25

26

27

28

29

30

31

32

33

34

35

36

37

38

39

40

41

42

43

44

45

46

47

48

49

50

51

52

53

54

55

56

57

58

59

60

John Wiley \& Sons, Inc. 


\section{METHODS}

\section{Study population and study design}

We used data from a population-based childhood cohort study from the UK, the second Leicestershire respiratory cohort. The study was approved by the Leicestershire Health Authority Research Ethics Committee. Details are published elsewhere. ${ }^{17}$ In short, a random sample of children born from May 1993 to April 1997, stratified by year of birth, sex, and ethnic group (South Asian or White) was selected from the Leicestershire Health Authority Child Health Database, which is comprised of perinatal, demographic, and health-related information for all children resident in the area of Leicestershire. Perinatal data came from birth records and growth data from prospective health-visitor records. We assessed respiratory symptoms through postal questionnaires mailed to parents in 1998, 1999, 2001, 2003, 2006, and 2010. In the first survey (1998), $78 \%$ of the families $(6,808 / 8,700)$ participated. In the following surveys, response rates were $74 \%, 63 \%, 51 \%, 37 \%$ and $33 \%$, respectively (Table E1). ${ }^{17}$ In 1998 most children were 1 year old $(\mathrm{N}=4,102), 52 \%$ were boys, and $20 \%$ were of South Asian ethnic origin (Table 1).

\section{Questionnaires and questions on wheezing illness}

The questionnaire defined wheeze as "breathing that makes a high-pitched whistling or squeaking sound from the chest, not the throat." We assessed current wheeze (wheeze occurring in the last 12 months) with the question from the ISAAC. ${ }^{13}$ In case of reported wheeze, we asked whether children wheezed only during or after a cold or flu, or also at times unassociated with these conditions, and we assessed trigger factors and aspects of severity (Table 2). ${ }^{18}$ Repeatability for questions on wheeze was very good (к $\left.0.61-0.80\right) .{ }^{19} \mathrm{We}$ grouped phenotypes into episodic viral wheeze if parents reported that children wheezed only with colds and multiple trigger wheeze if children also wheezed apart from colds. ${ }^{6,20} \mathrm{We}$ 
assessed these trigger factors: exercise (running or playing), aeroallergens (house dust, pollen, pets), food or drinks, laughing or crying or excitement. To describe severity of wheezing illness, we asked how many attacks the child had had in the past 12 months (defining frequent as $\geq 4$ episodes), ${ }^{1}$ and we inquired whether wheezing was accompanied by shortness of breath, led to sleep disturbance (duration $\geq 1$ week considered severe), or interfered with daily activities. The questionnaires were addressed to parents until the child reached 13 years (surveys in 1998, 1999, 2001, 2003, 2006), and directly to children from age 14 onwards (survey in 2010).

\section{Statistical analyses}

We included all children who participated in at least one survey $(7,670$ children, $88 \%)$. Due to the range in birth years (1993-7), children were age 1-4 years at the first survey in 1998 and 13-17 in 2010. For this analysis, we grouped children by age, rather than by survey, into the following age groups: 1 year, 2 years, 3-4, 5-6, 7-9, 10-13 and 14-17 years (Fig. E1). We formed narrower age groups in early childhood when physiological and environmental changes occur faster. Children were included only once in each age group (using the survey when children were closest to the midpoint of that age group) but could contribute information to several age groups if they had participated in more than one survey. For the analysis we thus used information on 4,102 children aged 1 year, 3,163 children aged 2, 4,071 aged 3-4, 4,031 aged 5-6, 3,244 aged 7-9, 2,204 aged 10-13, and 2,025 aged 14-17 years.

We calculated prevalence and $95 \%$ confidence intervals (CI) of current wheeze and of features of wheeze (wheeze induced by different triggers, wheeze severity markers). We did this for each age group in the entire cohort (absolute prevalence) and in children with current wheeze (relative prevalence). We assessed changes in prevalence with age using logistic generalised estimating equation (GEE) models with an exchangeable working correlation 
structure. These models estimate population-averaged changes in prevalence, accounting for repeated measurements of wheeze for children who participated in several surveys. ${ }^{21} \mathrm{We}$ calculated odds ratios (ORs) and 95\% CI for wheeze in younger and older children compared to the baseline group of children aged 5-6 years.

In a sensitivity analysis, we assessed the potential effect of attrition bias on our results. Attrition bias, caused by decreasing response rates, is common in cohort studies. Since nonresponders might comprise a different population than responders, attrition could distort the results so that they are no longer representative for the entire cohort. We explored whether attrition bias might have affected our results by using inverse probability weight and comparing weighted prevalence of outcomes to unweighted prevalence. To do this, we modelled the probability of participation at each survey with logistic regression models by assessing which baseline factors were associated with participation. We used the following factors: age, sex, ethnicity (White, South Asian), low birth weight $(<2,500$ g), gestational age ( $<37$ weeks), maternal age, Townsend deprivation index, ${ }^{22}$ living in an urban area (Leicester postcodes LE1-LE5), and participation in previous surveys. From these models we predicted individual response probabilities for different surveys and inverted them to obtain individual weights. ${ }^{23}$ In a further sensitivity analysis for those who were 14 to 17 years old, an age group in which we had both parent-reported and self-reported questionnaires (from the 2010 survey), we assessed whether results differed by type of respondent. We prepared and analysed the data using Stata 14.0 (Stata Corporation, Austin, Texas), and R version 3.3.0. 


\section{RESULTS}

Absolute prevalence of current wheeze, phenotypes, trigger factors, and severe wheeze in the entire cohort

Prevalence and features of wheeze varied significantly with age (Table 3 Panel a, Figs. 1 and 2). Current wheeze decreased in prevalence during preschool years from $36 \%$ in 1 -year-olds to $24 \%$ in 2-year-olds, $20 \%$ in $3-4$-year-olds, and $15-17 \%$ in schoolchildren irrespective of age (Table 3). This differed by wheeze phenotype. Absolute prevalence of EVW decreased steeply with age from $24 \%$ in 1 -year-olds to $5 \%$ in $7-9$-year-olds with no significant changes thereafter (Table E2). In contrast, MTW changed little with age. It was reported for $8-12 \%$ of children throughout childhood, with slightly higher prevalence in 1-year-olds and 10 to 17 year-olds compared to 5-6-year-olds (Table E2).

Furthermore, the presence of trigger factors also was age-dependent. Wheeze with exercise was reported for $8-9 \%$ of children until age 9 , then became more frequent, reaching $13 \%$ in adolescents (Table 3, Fig. 1; Table E3). Wheeze induced by aeroallergens was rare in 1-2year-olds (2-3\%), reported more often from age 5 onwards $(5 \%)$, and reached $10 \%$ in adolescents. Wheeze triggered by food or drinks remained rare (1-3\%) throughout childhood. Laughing or crying was reported to trigger wheeze in $10 \%$ of 1 -year-olds and $6 \%$ of 2 -yearolds, decreased in prevalence to $3 \%$ at age $3-4$, and again became slightly more common in adolescence (6\% at age $14-17)$.

Severe wheeze was rare in the entire cohort and changed little with age (Table 3, Fig. 1; Table E4). Frequent attacks ( $\geq 4$ /year) were reported most often for 1-year-olds (13\%); this decreased slowly to $5 \%$ at age $10-13$. Shortness of breath together with wheeze was rare and reported for only $2-5 \%$ of children throughout childhood. Sleep disturbance due to wheeze was most frequent in infants ( $9 \%)$, became gradually less common, and was reported for $2 \%$ 
of children aged 14-17. Interference of wheeze with daily activities was reported for $5 \%$ of infants and decreased slowly to $2 \%$ in adolescents.

Relative prevalence of wheeze phenotypes, trigger factors, and severe wheeze among children with current wheeze

Results looked different when viewed from a physician's perspective as a proportion of all children with current wheeze (Table 3 Panel b, Figs. 2-3 and Tables E5-7). At age 1, twothirds of children were reported to have the phenotype EVW and one-third MTW; this reversed to $60 \%$ with MTW and $40 \%$ with EVW in adolescents (Fig. 2).

The proportion of wheezing children with exercise-induced wheeze increased greatly, from $26 \%$ in infants to $78 \%$ in adolescents; this increase in relative prevalence (Fig. 3 ) was much steeper than the increase in absolute prevalence (Fig. 1). Similarly, aeroallergens were reported to trigger attacks in $6 \%$ of infants and around $60 \%$ of children age 10 or older. The proportion of children with wheeze reporting that attacks were triggered by food or drinks (8 to $13 \%$ ) or by laughter or crying (30 to $37 \%$ ) differed little between age groups.

About one-third of children with wheeze in all age groups (37\%) were reported to have frequent attacks ( $\geq 4$ /year) throughout childhood. In contrast, the proportion of current wheezers for whom parents reported shortness of breath increased with age from $7 \%$ at age 1 to $26 \%$ at age $14-17$ (Fig. 3). Sleep disturbance on the other hand became less important in older children: it was reported for $24 \%$ of 1 -year-old wheezing children, but for only $11 \%$ of 14-17-year-olds with current wheeze. Interference with daily activities was reported most often (20\%) for 3-9-year-olds.

\section{Sensitivity analyses}

The weighted results from the sensitivity analyses that adjusted for potential attrition bias were very similar to those from the unweighted analysis, suggesting that the results were not 
biased by the lower response rates (Tables E8, E9). The sensitivity analysis in 14-17-year-olds that compared parent-reported questions $(\mathrm{N}=749)$ with self-reported questions $(\mathrm{N}=1,072)$

from the 2010 survey found a mainly nonsignificant trend to lower prevalence when symptoms were reported by parents (Table E10). 


\section{DISCUSSION}

Wheezing illness presents with significant, age-related changes throughout entire childhood. While it is well known that wheezing illness changes with age, this is the first study to give a detailed picture from both a population perspective (absolute prevalence) and the perspective of a physician seeing children with current wheeze (relative prevalence). With the decline in episodic viral wheeze, current wheeze becomes less common with age. Multiple trigger wheeze remains stable across the entire cohort, but its proportion among wheezing children increases with increasing age. Laughing frequently triggers wheeze in younger children, whereas exercise and aeroallergens are more common triggers in adolescents.

\section{Strengths and limitations}

The main strengths of the study include (i) its large and representative sample from a population-based cohort, (ii) detailed age resolution from infancy through adolescence, (iii) standardised methodology, and (iv) the broad array of features studied, which include phenotypes, triggers, and severity. Because of attrition in later surveys, we also performed a weighted analysis, which showed results similar to the unweighted analysis suggesting that nonresponse bias did not affect our findings. A potential limitation is that symptoms were parent-reported. However, this reflects the reality of epidemiological surveys and clinical practice in which parents describe the symptoms of their children. As in other studies such as the ISAAC, we addressed questions to parents of younger children and directly to older children (from age 14 onwards). A sensitivity analysis in those aged 14-17 suggests that this did not affect the results much. As in most other studies, ${ }^{3,4}$ we assessed symptom prevalence retrospectively over the last 12 months; but our questions on wheeze had a good repeatability when asked again 3 months later. ${ }^{19}$ Finally, it could be argued that age-related changes might 
have been overlaid by temporal trends in prevalence of wheeze from 1998 to 2010. However, prevalence of wheezing illness in the Western world has levelled off in the last two decades. ${ }^{2}$

\section{Prevalence and phenotypes of wheeze}

Changes of prevalence with age have been documented rarely and only over limited age ranges, none covering the entire age range. However, the prevalence of wheeze we observed in children 6-7 and 13-14 years old appears comparable to that in reports on the same geographic region during the same period. ${ }^{3,4}$ Current wheeze decreased from $16 \%$ in 2 -yearolds to 7\% in 7-9-year-olds, in 3,963 children from the Prevention and Incidence of Asthma and Mite Allergy (PIAMA) birth cohort. ${ }^{12}$ In 370 Australian children in the Childhood Asthma Prevention Study (CAPS) cohort, wheeze decreased from 46\% of 1-year-olds to 25\% in 11-year-olds. ${ }^{24}$ Two yet earlier studies suggested a slight decrease in prevalence in schoolchildren from age 7 to $15 .^{25,26}$

Regarding wheeze phenotypes, we know that the proportion of children with EVW decreases with age, while the proportion with MTW increases. ${ }^{27-30}$ What is new in this study is that we showed a considerable proportion of children reporting EVW throughout childhood to the ages of 14 to 17 years, which may indicate that EVW is not restricted to preschoolers as is often suggested. ${ }^{6,29,31}$ Furthermore, we found that the prevalence of MTV-although increasing relatively as a proportion of all children with wheeze — does not change much in absolute numbers throughout childhood, affecting between 8 and 12\% of children at all ages. It has been questioned whether these phenotypes are stable over time and thus independent disorders. ${ }^{32,33}$ However, recent data from the Leicester Respiratory Cohorts and the Avon Longitudinal Study of Parents and Children cohort (ALSPAC) suggest that MTW and, to a lesser extent, EVW track throughout childhood, independent of severity, and thus seem to be separate disorders. ${ }^{34}$ Although allergic triggers (aeroallergens) become important only in late 
preschool years, wheeze was reported apart from colds for many infants and toddlers. Their symptoms in infection-free periods were not triggered by allergens, but mostly by activities associated with increased breathing effort (exercise, laughing, crying).

\section{Triggers and severity of wheeze}

Exercise was relevant for all age groups and was the most common trigger reported. While absolute prevalence of exercise-induced wheeze changed little with age ( 8 to $13 \%$ ), its importance among children with wheeze increased. It affected only one-quarter of 1-yearolds, but three-quarters of adolescents. In line with our results, an Australian study reported that at ages 7, 12, and 15 years, respectively $57 \%, 78 \%$, and $80 \%$ of Melbourne children with current wheeze reported exercise as a trigger. ${ }^{26}$ This study also reported an age-related increase of aeroallergen-triggered symptoms comparable to our results, from $6 \%$ at age 7 to $12 \%$ at age $15 .^{26}$ This mirrors the age-related increase in sensitization to inhaled allergens and atopic rhinitis described in other cohorts. ${ }^{35,36}$ Also, a US study in asthmatic children aged 220 years showed that the impact of allergy problems and physical activity in triggering asthma episodes increased with increasing age ${ }^{37}$ Wheeze triggered by food or drinks, which can be mediated via different mechanisms, has been described with a comparable prevalence $(1 \%$ in 1-5-year-olds) in the first Leicester cohort for 1,422 children born 1985-90. ${ }^{7}$

Severity of wheeze (frequency of attacks, shortness of breath, sleep disturbance, and activity restriction) has been assessed in other studies, ${ }^{3,9,12,38}$ but has rarely been compared between age groups. We found that the proportion of wheezing children with frequent attacks - about one-third-remains the same throughout childhood. The proportion of children with wheeze whose sleep is disturbed decreases from $24 \%$ in infants to $11 \%$ in adolescents. Shortness of breath increases in prevalence from $7 \%$ in infants to $26 \%$ in adolescents. This might partly be due to a better ability of older children to describe this symptom. Shortness of breath was 
more frequent in some German, ${ }^{38}$ Dutch, ${ }^{12}$ and Eastern European studies ${ }^{39,} 40$ compared to ours, but their questions were not all worded exactly the same, and interpretation might differ between languages.

\section{Interpretation of findings}

Our results are likely influenced by several factors that all change with age, including physiological, developmental, and environmental factors. Physiological changes, for instance an increase in the absolute diameter of the airways, and also the development of the immune system might explain the decreasing prevalence of virus-induced wheeze during the first years of life, while the increasing proportion of children sensitised to aeroallergens explains the rising relevance of aeroallergens as triggers. With increasing cognitive abilities, children are better able to express subjective symptoms such as shortness of breath. Disturbed sleep might seem less important in older children, whose sleep is monitored less closely by parents than it is in early childhood. Finally, exercise becomes more competitive in later school years so that limitations can no longer be avoided by an adapted lifestyle, but become obvious in comparison to peers. Nearly $80 \%$ of adolescents with wheeze reported exercise-induced symptoms in our study.

This study demonstrates in detail how prevalence and clinical presentation of wheeze vary with age and reflect fundamental immunological, physiological, and environmental changes. The results give a detailed picture of the burden of wheezing illness throughout childhood and are thus useful from a public health perspective for health-care planning. Future research projects can make use of the information on the trigger factors and severity indicators that are important for specific age groups to design their questionnaires. 
A clear understanding of age-related patterns, including trigger factors and markers of severity, is essential for providing clinical care and conducting and interpreting research studies. 


\section{ACKNOWLEDGEMENTS}

We thank the parents of the Leicestershire respiratory cohort children for completing the questionnaires. We thank Marcel Zwahlen (ISPM, University of Bern, Switzerland), Alban Ramette (ISPM, University of Bern, Switzerland), and Marie-Pierre Strippoli (University of Lausanne, Switzerland) for their support with the statistical analyses, as well as Graeme Torrance (ISPM, University of Bern, Switzerland) for his contribution to creating Fig. E1. We thank Christopher Ritter (ISPM, University of Bern, Switzerland) for editorial assistance.

\section{Competing interests}

None 


\section{REFERENCES}

1. Lai CK, Beasley R, Crane J, Foliaki S, Shah J, Weiland S, et al. Global variation in the prevalence and severity of asthma symptoms: phase three of the International Study of Asthma and Allergies in Childhood (ISAAC). Thorax. 2009;64(6):476-483.

2. Patel SP, Jarvelin MR, Little MP. Systematic review of worldwide variations of the prevalence of wheezing symptoms in children. Environ Health. 2008;7:57.

3. Pearce N, Ait-Khaled N, Beasley R, Mallol J, Keil U, Mitchell E, et al. Worldwide trends in the prevalence of asthma symptoms: phase III of the International Study of Asthma and Allergies in Childhood (ISAAC). Thorax. 2007;62(9):758-766.

4. Asher MI, Montefort S, Bjorksten B, Lai CK, Strachan DP, Weiland SK, et al. Worldwide time trends in the prevalence of symptoms of asthma, allergic rhinoconjunctivitis, and eczema in childhood: ISAAC Phases One and Three repeat multicountry cross-sectional surveys. Lancet. 2006;368(9537):733-743.

5. Schultz A, Brand PL. Episodic viral wheeze and multiple trigger wheeze in preschool children: a useful distinction for clinicians? Paediatr Respir Rev. 2011;12(3):160-164.

6. Brand PL, Baraldi E, Bisgaard H, Boner AL, Castro-Rodriguez JA, Custovic A, et al. Definition, assessment and treatment of wheezing disorders in preschool children: an evidence-based approach. Eur Respir J. 2008;32(4):1096-1110.

7. Kuehni CE, Davis A, Brooke AM, Silverman M. Are all wheezing disorders in very young (preschool) children increasing in prevalence? Lancet. 2001;357(9271):1821-1825.

8. Hermann C, De Fine Olivarius N, Host A, Begtrup K, Hollnagel H. Prevalence, severity and determinants of asthma in Danish five-year-olds. Acta Paediatr. 2006;95(10):1182-1190.

9. Leonardi GS, Houthuijs D, Nikiforov B, Volf J, Rudnai P, Zejda J, et al. Respiratory symptoms, bronchitis and asthma in children of Central and Eastern Europe. Eur Respir J. 2002;20(4):890-898.

10. Porsbjerg C, von Linstow ML, Ulrik CS, Nepper-Christensen S, Backer V. Risk factors for onset of asthma: a 12-year prospective follow-up study. Chest. 2006;129(2):309-316. 
11. Carlsten C, Brauer M, Dimich-Ward H, Dybuncio A, Becker AB, Chan-Yeung M. Combined exposure to dog and indoor pollution: incident asthma in a high-risk birth cohort. Eur Respir J. 2011;37(2):324-330.

12. Caudri D, Wijga AH, Smit HA, Koppelman GH, Kerkhof M, Hoekstra MO, et al. Asthma symptoms and medication in the PIAMA birth cohort: evidence for under and overtreatment. Pediatr Allergy Immunol. 2011;22(7):652-659.

13. Asher MI, Keil U, Anderson HR, Beasley R, Crane J, Martinez F, et al. International Study of Asthma and Allergies in Childhood (ISAAC): rationale and methods. Eur Respir J. $1995 ; 8(3): 483-491$.

14. Linehan MF, Frank PI, Niven R, Hazell ML, Morris JA, Francis H, et al. Prevalence of respiratory symptoms, features of asthma, and characteristics associated with respiratory disease, in 6-11 year olds in Manchester. Prim Care Respir J. 2009;18(1):21-26.

15. Ranciere F, Nikasinovic L, Bousquet J, Momas I. Onset and persistence of respiratory/allergic symptoms in preschoolers: new insights from the PARIS birth cohort. Allergy. 2013;68(9):1158-1167.

16. Depner M, Fuchs O, Genuneit J, Karvonen AM, Hyvarinen A, Kaulek V, et al. Clinical and epidemiologic phenotypes of childhood asthma. Am J Respir Crit Care Med. 2014;189(2):129-138.

17. Kuehni CE, Brooke AM, Strippoli MP, Spycher BD, Davis A, Silverman M. Cohort profile: the Leicester respiratory cohorts. Int J Epidemiol. 2007;36(5):977-985.

18. Ferris BG. Epidemiology Standardization Project (American Thoracic Society). Am Rev Respir Dis. 1978;118(6 Pt 2):1-120.

19. Strippoli MP, Silverman M, Michel G, Kuehni CE. A parent-completed respiratory questionnaire for 1-year-old children: repeatability. Arch Dis Child. 2007;92(10):861-865.

20. Spycher BD, Silverman M, Kuehni CE. Phenotypes of childhood asthma: are they real? Clin Exp Allergy. 2010;40(8):1130-1141.

21. Liang KY, Zeger SL. Regression analysis for correlated data. Annu Rev Public Health. $1993 ; 14: 43-68$. 
22. Townsend P, Philimore P, Beattie A. Health and deprivation: inequality and the North. Bristol: Croom Helm; 1988.

23. Austin PC. An Introduction to Propensity Score Methods for Reducing the Effects of Confounding in Observational Studies. Multivariate Behav Res. 2011;46(3):399-424.

24. Garden FL, Simpson JM, Mellis CM, Marks GB. Change in the manifestations of asthma and asthma-related traits in childhood: a latent transition analysis. Eur Respir J. 2016;47(2):499509.

25. Sennhauser FH, Kuhni CE. Prevalence of respiratory symptoms in Swiss children: is bronchial asthma really more prevalent in boys? Pediatr Pulmonol. 1995;19(3):161-166.

26. Robertson CF, Heycock E, Bishop J, Nolan T, Olinsky A, Phelan PD. Prevalence of asthma in Melbourne schoolchildren: changes over 26 years. BMJ. 1991;302(6785):1116-1118.

27. Just J, Saint Pierre P, Amat F, Gouvis-Echraghi R, Lambert-Guillemot N, Guiddir T, et al. What lessons can be learned about asthma phenotypes in children from cohort studies? Pediatr Allergy Immunol. 2015;26(4):300-305.

28. Strippoli MP, Spycher BD, Pescatore AM, Beardsmore CS, Silverman M, Kuehni CE. Exclusive viral wheeze and allergic wheeze: evidence for discrete phenotypes. Eur Respir J. $2011 ; 38(2): 472-474$.

29. Martinez FD, Wright AL, Taussig LM, Holberg CJ, Halonen M, Morgan WJ. Asthma and wheezing in the first six years of life. The Group Health Medical Associates. N Engl J Med. 1995;332(3):133-138.

30. Wassall HJ, Devenny AM, Daud Khan S, Ninan TK, Russell G. A comparison of virusassociated and multi-trigger wheeze in school children. J Asthma. 2005;42(9):737-744.

31. Kurukulaaratchy RJ, Fenn MH, Waterhouse LM, Matthews SM, Holgate ST, Arshad SH. Characterization of wheezing phenotypes in the first 10 years of life. Clin Exp Allergy. 2003;33(5):573-578.

32. Schultz A, Devadason SG, Savenije OE, Sly PD, Le Souef PN, Brand PL. The transient value of classifying preschool wheeze into episodic viral wheeze and multiple trigger wheeze. Acta Paediatr. 2010;99(1):56-60. 
33. van Wonderen KE, Geskus RB, van Aalderen WM, Mohrs J, Bindels PJ, van der Mark LB, et al. Stability and predictiveness of multiple trigger and episodic viral wheeze in preschoolers. Clin Exp Allergy. 2016;46(6):837-847.

34. Spycher BD, Cochrane C, Granell R, Sterne J, Silverman M, Pedersen E, et al. Temporal stability of multiple trigger and episodic viral wheeze in early childhood. Eur Respir J. 2017; In press.

35. Kurukulaaratchy RJ, Karmaus W, Raza A, Matthews S, Roberts G, Arshad SH. The influence of gender and atopy on the natural history of rhinitis in the first 18 years of life. Clin Exp Allergy. 2011;41(6):851-859.

36. Nissen SP, Kjaer HF, Host A, Nielsen J, Halken S. The natural course of sensitization and allergic diseases from childhood to adulthood. Pediatr Allergy Immunol. 2013;24(6):549-555.

37. Sarafino EP, Paterson ME, Murphy EL. Age and the impacts of triggers in childhood asthma. J Asthma. 1998;35(2):213-217.

38. von Mutius E, Fritzsch C, Weiland SK, Roll G, Magnussen H. Prevalence of asthma and allergic disorders among children in united Germany: a descriptive comparison. BMJ. 1992;305(6866):1395-1399.

39. Leonardi NA, Spycher BD, Strippoli MP, Frey U, Silverman M, Kuehni CE. Validation of the Asthma Predictive Index and comparison with simpler clinical prediction rules. J Allergy Clin Immunol. 2011;127(6):1466-1472.e1466.

40. Timonen KL, Pekkanen J, Korppi M, Vahteristo M, Salonen RO. Prevalence and characteristics of children with chronic respiratory symptoms in eastern Finland. Eur Respir J. 1995;8(7):1155-1160. 
Table E1-Response rates for questionnaire surveys

\begin{tabular}{|c|c|c|c|c|c|}
\hline Year of survey & $\mathrm{N}_{\text {contacted }}$ & $\mathrm{N}_{\text {replied }}$ & $\begin{array}{l}\text { Response } \\
\text { rate A } \\
\%^{\mathrm{c}}\end{array}$ & $\begin{array}{l}\text { Response } \\
\text { rate } \mathrm{B} \\
\%^{\mathrm{d}}\end{array}$ & $\begin{array}{l}\text { Age of the child when } \\
\text { questionnaire was filled } \\
\text { in (years) }\end{array}$ \\
\hline 1998 & $8,700^{\mathrm{a}}$ & 6,808 & 78.3 & 78.3 & 0.7 to 5.5 \\
\hline $1999^{b}$ & 3,241 & 2,407 & 74.3 & $-^{\mathrm{b}}$ & 1.9 to 3.2 \\
\hline 2001 & 8,225 & 5,212 & 63.4 & 59.9 & 3.9 to 8.5 \\
\hline 2003 & 8,283 & 4,236 & 51.1 & 48.7 & 5.9 to 10.2 \\
\hline 2006 & 8,233 & 3,028 & 36.7 & 34.8 & 8.3 to 13.9 \\
\hline 2010 & 7,642 & 2,544 & 33.3 & 29.2 & 13.1 to 17.9 \\
\hline
\end{tabular}

${ }^{a}$ After the age of 5 years, the address database was not updated, thus we did not have valid addresses for all children and not all 8,700 children were contacted at different surveys

${ }^{\mathrm{b}}$ Questionnaire only for a subsample, for those who were aged 1 year in 1998 and had replied to the questionnaire in 1998

${ }^{\mathrm{c}}$ Response rate A: number of participants who replied/ number of participants who were contacted at the respective survey (for instance for the 2010 survey: 2,544/7,642)

${ }^{\mathrm{d}}$ Response rate B: number of participants who replied/ number of originally sampled children (for instance for the 2010 survey: $2,544 / 8,700$ ). 
TABLE 1 - Characteristics of the study population aged 1 year $(\mathrm{N}=4,102)$

\begin{tabular}{|c|c|c|c|}
\hline & & $\mathrm{n}$ & $(\%)$ \\
\hline \multicolumn{4}{|l|}{ Demographic factors } \\
\hline \multicolumn{2}{|l|}{ Age (years, mean[SD]) } & 1.5 & {$[0.3]$} \\
\hline \multicolumn{2}{|l|}{ Male } & 2,136 & $(52)$ \\
\hline \multirow[t]{2}{*}{ Ethnicity } & White & 3,301 & $(80)$ \\
\hline & South Asian & 801 & (20) \\
\hline \multicolumn{4}{|l|}{ Perinatal and early life factors } \\
\hline \multicolumn{2}{|l|}{ Low birth weight $(<2500 \mathrm{~g})$} & 279 & (7) \\
\hline \multicolumn{2}{|l|}{ Gestational age $<37$ weeks } & 277 & (7) \\
\hline \multicolumn{2}{|l|}{ Breastfed } & 2,400 & $(58)$ \\
\hline \multicolumn{4}{|l|}{ Symptoms of the child } \\
\hline \multicolumn{2}{|l|}{ Current wheeze } & 1,447 & $(36)$ \\
\hline \multicolumn{2}{|l|}{ Cough without colds } & 1,403 & (34) \\
\hline \multirow[t]{3}{*}{ Number of colds (in the last 12 months) } & $0-3$ & 1,862 & $(45)$ \\
\hline & $4-6$ & 1,457 & (36) \\
\hline & $\geq 7$ & 772 & (19) \\
\hline \multicolumn{4}{|l|}{ Environmental exposures } \\
\hline \multicolumn{2}{|l|}{ Nursery care } & 1,040 & $(25)$ \\
\hline \multirow[t]{3}{*}{ Number of older siblings } & 0 & 1,292 & (32) \\
\hline & 1 or 2 & 2,228 & (54) \\
\hline & & 381 & (9) \\
\hline \multicolumn{2}{|l|}{ Pet ownership } & 1,662 & (41) \\
\hline \multicolumn{2}{|l|}{ Mother smoking during pregnancy } & 688 & (17) \\
\hline \multicolumn{2}{|l|}{ Mother smoking (postnatal) } & 889 & $(22)$ \\
\hline \multicolumn{2}{|l|}{ Father smoking } & 1,029 & $(25)$ \\
\hline \multicolumn{4}{|l|}{ Socioeconomic factors } \\
\hline \multicolumn{2}{|l|}{ Higher parental education ${ }^{\mathrm{a}}$} & 2,350 & (57) \\
\hline \multicolumn{2}{|l|}{ More deprived Townsend deprivation index } & 610 & (15) \\
\hline \multicolumn{4}{|l|}{ Parental history of atopic diseases } \\
\hline \multicolumn{2}{|l|}{ Hay fever (mother or father) } & 1,846 & $(45)$ \\
\hline \multicolumn{2}{|l|}{ Wheeze or asthma (mother or father) } & 1,354 & (33) \\
\hline
\end{tabular}

${ }^{a}$ Age at the end of education is $>16$ years

${ }^{\mathrm{b}}$ The categories cover the following Townsend Deprivation Index intervals: more affluent [-6.222, -2.635], affluent [-2.615, -0.707], average [-0.705, 1.859], deprived [1.861, 5.147], more deprived [5.160, 11.072] 
TABLE 2-Original questions about wheezing characteristics analysed in this study

\begin{tabular}{|c|c|}
\hline Question & Source of the question \\
\hline $\begin{array}{l}\text { Current wheeze } \\
\text { Has your child had wheezing or whistling in the chest in the last } 12 \text { months? } \\
\square \text { yes } \\
\square \text { no }\end{array}$ & $\begin{array}{l}\text { International Study of } \\
\text { Asthma and Allergy in } \\
\text { Childhood (ISAAC) }\end{array}$ \\
\hline \multicolumn{2}{|l|}{ Ifyes: } \\
\hline $\begin{array}{l}\text { In the last } 12 \text { months, has your child had wheezing or whistling in the chest } \\
\text { during or soon after a cold or flu? } \\
\square \text { yes } \\
\square \text { no }\end{array}$ & $\begin{array}{l}\text { Adapted from American } \\
\text { Thoracic Society } \\
\text { questionnaires }^{18}\end{array}$ \\
\hline $\begin{array}{l}\text { In the last } 12 \text { months, has your child had wheezing or whistling in the chest even } \\
\text { without having a cold or flu? } \\
\square \text { yes } \\
\square \text { no }\end{array}$ & $\begin{array}{l}\text { Adapted from American } \\
\text { Thoracic Society } \\
\text { questionnaires }^{18}\end{array}$ \\
\hline $\begin{array}{l}\text { In the last } 12 \text { months did the following things cause wheezing in your child? } \\
\square \text { Exercise (playing, running) } \\
\square \text { House dust } \\
\square \text { Pollen (grass, hay, trees, flowers) } \\
\square \text { Contact with pets or other animals } \\
\square \text { Food or drinks } \\
\square \text { Laughing, crying or excitement }\end{array}$ & $\begin{array}{l}\text { Adapted from the earlier } \\
\text { questionnaire used in } \\
\text { Leicestershire } \\
\text { (Leicester Respiratory } \\
\text { Cohort 1990) }\end{array}$ \\
\hline $\begin{array}{l}\text { How many attacks of wheezing has your child had during the last } 12 \text { months? } \\
\square \text { None } \\
\square 1 \text { to } 3 \\
\square 4 \text { to } 12 \\
\square \text { More than } 12\end{array}$ & ISAAC $^{13}$ \\
\hline $\begin{array}{l}\text { Do these attacks cause him/her to be short of breath? } \\
\square \text { Yes, always } \\
\square \text { Yes, occasionally } \\
\square \text { No, never }\end{array}$ & $\begin{array}{l}\text { Verbatim earlier } \\
\text { questionnaire used in } \\
\text { Leicestershire (Leicester } \\
\text { Respiratory Cohort 1990) }\end{array}$ \\
\hline $\begin{array}{l}\text { In the last } 12 \text { months, how often, on average, has your child's sleep been } \\
\text { disturbed due to wheezing? } \\
\square \text { Never woken with wheezing } \\
\square \text { Less than one night per week } \\
\square \text { One or more nights per week }\end{array}$ & ISAAC $^{13}$ \\
\hline $\begin{array}{l}\text { In the last } 12 \text { months, how much did wheezing interfere with your child's daily } \\
\text { activities? } \\
\square \text { Not at all } \\
\square \text { A little } \\
\square \text { A moderate amount } \\
\square \text { A lot }\end{array}$ & ISAAC $^{13}$ \\
\hline
\end{tabular}




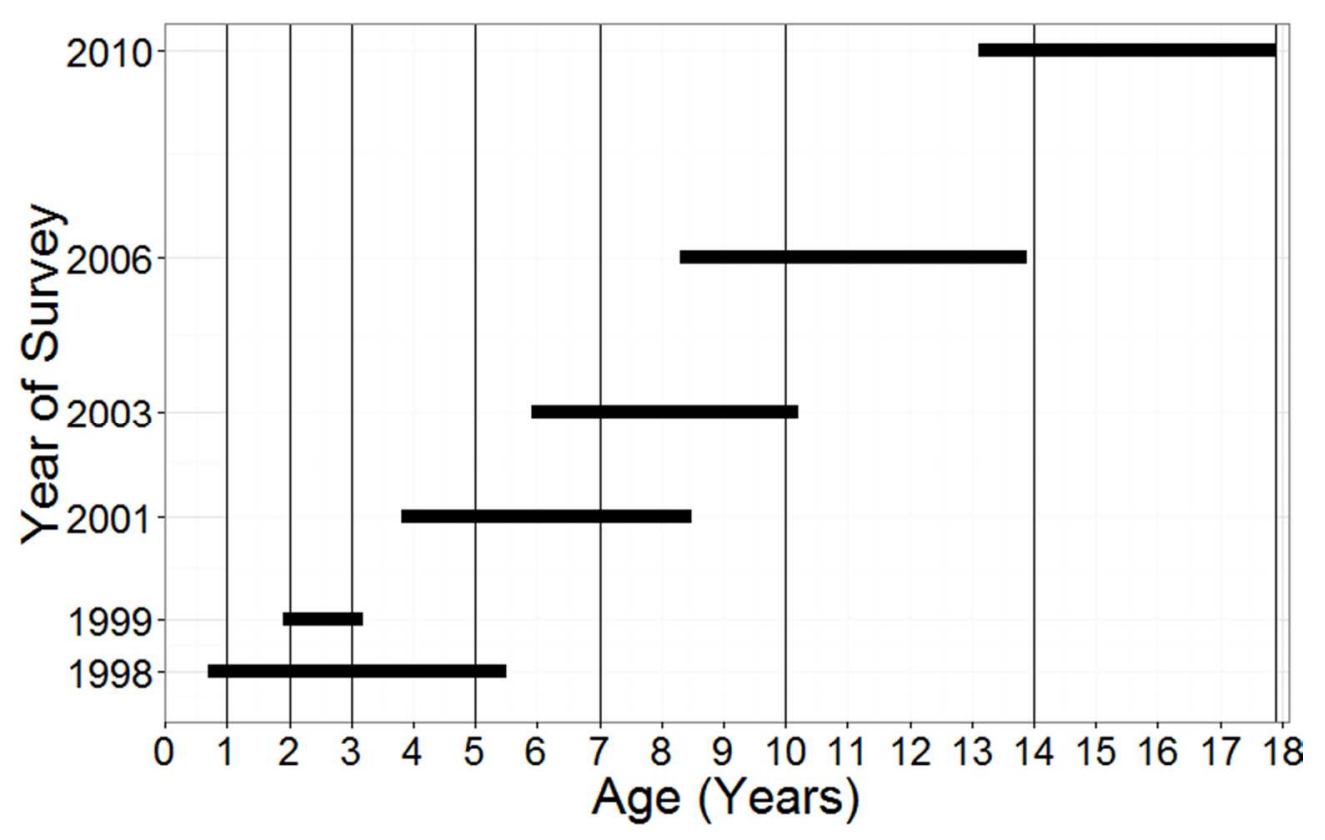

206×130mm (96 x 96 DPI)

John Wiley \& Sons, Inc. 


\section{TABLE 3-Prevalence of current wheeze, wheeze with triggers, and indicators of severe wheeze in children from age 1 to 17}

2a) Absolute prevalence: proportion of children with wheeze in entire cohort

2b) Relative prevalence: proportion of children with certain features of wheeze among wheezers

\begin{tabular}{|c|c|c|c|c|c|c|c|c|c|c|c|c|c|c|}
\hline \multirow{2}{*}{$\begin{array}{l}\text { Age (years): } \\
\text { 2a) Absolute prevalence (in entire cohort) }\end{array}$} & \multicolumn{2}{|c|}{$1(\mathrm{~N}=4,102)$} & \multicolumn{2}{|c|}{$2(\mathrm{~N}=3,163)$} & \multicolumn{2}{|c|}{ 3-4 $(\mathrm{N}=4,071)$} & \multicolumn{2}{|c|}{$5-6(N=4,031)$} & \multicolumn{2}{|c|}{ 7-9 $(\mathrm{N}=3,244)$} & \multicolumn{2}{|c|}{$10-13(\mathrm{~N}=2,204)$} & \multicolumn{2}{|c|}{$14-17(\mathrm{~N}=2,025)$} \\
\hline & $\mathrm{n}$ & $\%(95 \% \mathrm{CI})$ & $\mathrm{n}$ & $\%(95 \% \mathrm{CI})$ & $\mathrm{n}$ & $\%(95 \% \mathrm{CI})$ & $\mathrm{n}$ & $\%(95 \% \mathrm{CI})$ & $\mathrm{n}$ & $\%(95 \% \mathrm{CI})$ & $\mathrm{n}$ & $\%(95 \% \mathrm{CI})$ & $\mathrm{n}$ & $\%(95 \% \mathrm{CI})$ \\
\hline Wheeze & 1,447 & $36(34-37)$ & 744 & $24(23-26)$ & 810 & $20(19-21)$ & 675 & $17(16-18)$ & 465 & $15(13-16)$ & 362 & $17(15-18)$ & 336 & $17(15-18)$ \\
\hline Episodic viral wheeze & 955 & $24(23-25)$ & 486 & $16(15-17)$ & 445 & $11(10-12)$ & 356 & $9(8-10)$ & 173 & $5(5-6)$ & 139 & $6(5-8)$ & 122 & $7(5-8)$ \\
\hline Multiple trigger wheeze & 459 & $12(11-12)$ & 233 & $8(7-9)$ & 319 & $8(7-9)$ & 299 & $8(7-8)$ & 272 & $9(8-10)$ & 208 & $10(8-11)$ & 183 & $10(8-11)$ \\
\hline \multicolumn{15}{|l|}{ Triggers of wheeze } \\
\hline Exercise & 331 & $9(8-9)$ & 246 & $8(7-9)$ & 306 & $8(7-9)$ & 305 & $8(7-9)$ & 266 & $9(8-9)$ & 236 & $11(10-12)$ & 255 & $13(12-14)$ \\
\hline Aeroallergens & 77 & $2(2-3)$ & 74 & $3(2-3)$ & 200 & $5(5-6)$ & 236 & $6(5-7)$ & 218 & $7(6-8)$ & 205 & $10(8-11)$ & 188 & $10(8-11)$ \\
\hline Food/drinks & 103 & $3(2-3)$ & 48 & $2(1-2)$ & 52 & $1(1-2)$ & 59 & $2(1-2)$ & 50 & $2(1-2)$ & 37 & $2(1-2)$ & 26 & $1(1-2)$ \\
\hline Laughing/crying & 383 & $10(9-11)$ & 164 & $6(5-7)$ & 112 & $3(3-4)$ & 137 & $4(3-4)$ & 76 & $3(2-3)$ & 102 & $5(4-6)$ & 118 & $6(5-7)$ \\
\hline \multicolumn{15}{|l|}{ Indicators of severe wheeze } \\
\hline$\geq 4$ wheezing attacks & 504 & $13(12-14)$ & 258 & $8(7-9)$ & 318 & $8(7-9)$ & 249 & $6(6-7)$ & 208 & $7(6-7)$ & 116 & $5(4-6)$ & 104 & $5(4-6)$ \\
\hline Shortness of breath due to wheeze & 95 & $2(2-3)$ & 76 & $3(2-3)$ & 76 & $4(3-4)$ & 47 & $3(2-4)$ & 84 & $3(2-3)$ & 72 & $4(3-4)$ & 85 & $5(4-5)$ \\
\hline Sleep disturbed $>1 /$ week due to wheeze & 345 & $9(8-10)$ & 155 & $5(4-6)$ & 172 & $4(4-5)$ & 140 & $4(3-4)$ & 88 & $3(2-3)$ & 46 & $2(2-3)$ & 36 & $2(1-3)$ \\
\hline $\begin{array}{l}\text { Wheeze interfering moderately or a lot } \\
\text { with daily activities }\end{array}$ & 185 & $5(4-5)$ & 105 & $3(3-4)$ & 155 & $4(3-5)$ & 134 & $4(3-4)$ & 92 & $3(2-4)$ & 49 & $2(2-3)$ & 39 & $2(1-3)$ \\
\hline Age (years): & \multicolumn{2}{|c|}{$1(\mathrm{~N}=1,447)$} & \multicolumn{2}{|c|}{$2(\mathrm{~N}=744)$} & \multicolumn{2}{|c|}{$3-4(N=810)$} & \multicolumn{2}{|c|}{$5-6(N=675)$} & \multicolumn{2}{|c|}{$7-9(N=465)$} & \multicolumn{2}{|c|}{$10-13(\mathrm{~N}=362)$} & \multicolumn{2}{|c|}{$14-17(\mathrm{~N}=336)$} \\
\hline 2b) Relative prevalence (among wheezers) & $\mathrm{N}$ & $\%(95 \% \mathrm{CI})$ & $\mathrm{n}$ & $\%(95 \% \mathrm{CI})$ & $\mathrm{n}$ & $\%(95 \% \mathrm{CI})$ & $\mathrm{n}$ & $\%(95 \% \mathrm{CI})$ & $\mathrm{n}$ & $\%(95 \% \mathrm{CI})$ & $\mathrm{n}$ & $\%(95 \% \mathrm{CI})$ & $\mathrm{n}$ & $\%(95 \% \mathrm{CI})$ \\
\hline Episodic viral wheeze & 955 & $68(65-70)$ & 486 & $68(64-71)$ & 445 & $58(55-62)$ & 356 & $54(51-58)$ & 173 & $39(34-43)$ & 139 & $40(35-45)$ & 122 & $40(35-46)$ \\
\hline Multiple trigger wheeze & 459 & $33(30-35)$ & 233 & $32(29-36)$ & 319 & $42(38-45)$ & 299 & $46(42-50)$ & 272 & $61(56-65)$ & 208 & $60(55-65)$ & 183 & $60(55-66)$ \\
\hline \multicolumn{15}{|l|}{ Triggers of wheeze } \\
\hline Exercise & 331 & $26(24-28)$ & 246 & $38(34-41)$ & 306 & $44(40-48)$ & 305 & $50(46-54)$ & 266 & $62(58-67)$ & 236 & $67(62-71)$ & 255 & $78(73-82)$ \\
\hline Aeroallergens & 77 & $6(5-8)$ & 74 & $12(9-14)$ & 200 & $30(27-34)$ & 236 & $39(35-43)$ & 218 & $52(49-59)$ & 205 & $58(53-64)$ & 188 & $58(52-63)$ \\
\hline Food/drinks & 103 & $8(7-10)$ & 48 & $8(6-10)$ & 52 & $8(6-10)$ & 59 & $10(8-13)$ & 50 & $13(9-16)$ & 37 & $11(8-15)$ & 26 & $8(5-11)$ \\
\hline Laughing/crying & 383 & $34(31-37)$ & 164 & $33(28-37)$ & 112 & $33(28-38)$ & 137 & $35(31-40)$ & 76 & $30(25-36)$ & 102 & $31(26-36)$ & 118 & $37(31-42)$ \\
\hline \multicolumn{15}{|l|}{ Indicators of severe wheeze } \\
\hline$\geq 4$ wheezing attacks & 504 & $35(33-38)$ & 258 & $35(32-39)$ & 318 & $40(36-43)$ & 249 & $37(34-41)$ & 208 & $45(41-50)$ & 116 & $32(27-37)$ & 104 & $32(27-37)$ \\
\hline Shortness of breath due to wheeze & 95 & $7(5-8)$ & 76 & $10(8-13)$ & 76 & $17(14-21)$ & 47 & $17(13-22)$ & 84 & $19(15-22)$ & 72 & $21(16-25)$ & 85 & $26(21-31)$ \\
\hline Sleep disturbed $>1 /$ week due to wheeze & 345 & $24(22-27)$ & 155 & $21(18-26)$ & 172 & $22(19-25)$ & 140 & $21(18-24)$ & 88 & $19(15-23)$ & 46 & $13(10-17)$ & 36 & $11(8-14)$ \\
\hline $\begin{array}{l}\text { Wheeze interfering moderately or a lot } \\
\text { with daily activities }\end{array}$ & 185 & $13(11-15)$ & 105 & $14(12-17)$ & 155 & $20(17-22)$ & 134 & $20(17-23)$ & 92 & $20(16-23)$ & 49 & $14(10-18)$ & 39 & $12(8-16)$ \\
\hline
\end{tabular}

$\mathrm{N}$, number of children who returned the questionnaire at the respective age

Percentages are calculated based on those who responded to the respective questions

All wheeze features refer to the past 12 months 
Fig. 1. Absolute prevalence of wheeze, triggered by different factors, and of different indicators of wheeze severity in entire cohort of children from age 1 to 17 years. Prevalence presented as proportion (in \%) with $95 \%$ confidence intervals.

$338 \times 150 \mathrm{~mm}(96 \times 96$ DPI)

John Wiley \& Sons, Inc. 
Fig. 2. Prevalence of episodic viral wheeze and of multiple trigger wheeze in the entire cohort (absolute prevalence) and among children with current wheeze (relative prevalence, from age 1 to 17 years. Prevalence is presented as proportion (in \%) with $95 \%$ confidence intervals.

$338 \times 190 \mathrm{~mm}(96 \times 96 \mathrm{DPI})$

John Wiley \& Sons, Inc. 
Table E2-Age-related change in prevalence of wheeze (current, episodic viral, and multiple trigger) in entire cohort, presented as OR for different age groups*

\begin{tabular}{lllllll}
\hline & \multicolumn{2}{l}{ Wheeze } & \multicolumn{2}{l}{ Episodic viral wheeze } & \multicolumn{2}{l}{ Multiple trigger wheeze } \\
Age groups (years) & OR & $(95 \% \mathrm{CI})$ & OR & $(95 \% \mathrm{CI})$ & OR & $(95 \% \mathrm{CI})$ \\
\hline $\mathbf{1}$ & 2.7 & $(2.4-2.9)$ & 3.1 & $(2.8-3.5)$ & 1.5 & $(1.4-1.8)$ \\
$\mathbf{2}$ & 1.5 & $(1.4-1.7)$ & 1.9 & $(1.6-2.1)$ & 1.0 & $(0.8-1.2)$ \\
$\mathbf{3 - 4}$ & 1.2 & $(1.1-1.4)$ & 1.3 & $(1.1-1.5)$ & 1.1 & $(0.9-1.2)$ \\
$\mathbf{5 - 6}$ (reference) & 1.0 & & 1.0 & & 1.0 & \\
$\mathbf{7 - 9}$ & 0.8 & $(0.8-0.9)$ & 0.6 & $(0.5-0.7)$ & 1.2 & $(1.0-1.3)$ \\
$\mathbf{1 0 - 1 3}$ & 1.0 & $(0.9-1.2)$ & 0.7 & $(0.6-0.9)$ & 1.4 & $(1.2-1.6)$ \\
$\mathbf{1 4 - 1 7}$ & 1.0 & $(0.9-1.2)$ & 0.7 & $(0.6-0.9)$ & 1.4 & $(1.2-1.7)$ \\
\hline
\end{tabular}

*Age-related change: test for the significance of change in prevalence with age for each of the symptoms, calculated with GEE and presented as odds ratio of change in prevalence per age group with respective p-values, accounting for repeated nature of measurements and clustered data. Baseline group: 5-6-year-old children. All symptoms refer to the past 12 months.

$\mathrm{OR}$, odds ratio (GEE, generalised estimating equations, analysis) 
Table E3-Age-related change in prevalence of wheeze with triggers in entire cohort, presented as OR, for different age groups*

\begin{tabular}{|c|c|c|c|c|c|c|c|c|}
\hline \multirow[b]{2}{*}{ Age groups (years) } & \multicolumn{2}{|c|}{ Exercise } & \multicolumn{2}{|c|}{ Aeroallergens } & \multicolumn{2}{|c|}{ Food/drinks } & \multicolumn{2}{|c|}{ Laughing/crying } \\
\hline & OR & $(95 \% \mathrm{CI})$ & OR & $(95 \% \mathrm{CI})$ & OR & $(95 \% \mathrm{CI})$ & OR & $(95 \% \mathrm{CI})$ \\
\hline 1 & 1.1 & $(0.9-1.2)$ & 0.3 & $(0.2-0.4)$ & 1.7 & $(1.3-2.3)$ & 2.6 & $(2.2-3.1)$ \\
\hline 2 & 1.0 & $(0.9-1.2)$ & 0.4 & $(0.3-0.5)$ & 1.1 & $(0.7-1.5)$ & 1.4 & $(1.2-1.8)$ \\
\hline $3-4$ & 1.0 & $(0.9-1.2)$ & 0.9 & $(0.7-1.0)$ & 0.9 & $(0.6-1.3)$ & 0.9 & $(0.7-1.1)$ \\
\hline 5-6 (reference) & 1.0 & & 1.0 & & 1.0 & & 1.0 & \\
\hline $7-9$ & 1.1 & $(1.0-1.3)$ & 1.2 & $(1.0-1.4)$ & 1.0 & $(0.7-1.4)$ & 0.8 & $(0.6-1.0)$ \\
\hline $10-13$ & 1.5 & $(1.3-1.8)$ & 1.7 & $(1.4-2.0)$ & 1.2 & $(0.8-1.7)$ & 1.4 & $(1.1-1.8)$ \\
\hline 14-17 & 1.8 & $(1.6-2.1)$ & 1.7 & $(1.4-2.0)$ & 0.8 & $(0.5-1.3)$ & 1.8 & $(1.4-2.2)$ \\
\hline
\end{tabular}


Table E4-Age-related change in prevalence of indicators of wheeze severity in entire cohort, presented as OR, for different age groups*

\begin{tabular}{|c|c|c|c|c|c|c|c|c|}
\hline \multirow[b]{2}{*}{ Age groups (years) } & \multicolumn{2}{|c|}{ Frequent wheeze $^{a}$} & \multicolumn{2}{|c|}{ Shortness of breath ${ }^{b}$} & \multicolumn{2}{|c|}{ Sleep disturbance ${ }^{c}$} & \multicolumn{2}{|c|}{ Daily activities disturbance $^{\mathrm{d}}$} \\
\hline & OR & $(95 \% \mathrm{CI})$ & OR & $(95 \% \mathrm{CI})$ & OR & $(95 \% \mathrm{CI})$ & OR & $(95 \% \mathrm{CI})$ \\
\hline 1 & 2.1 & $(1.8-2.4)$ & 0.8 & $(0.6-1.1)$ & 2.5 & $(2.1-3.0)$ & 1.4 & $(1.1-1.7)$ \\
\hline 2 & 1.4 & $(1.2-1.6)$ & 0.8 & $(0.6-1.2)$ & 1.4 & $(1.2-1.8)$ & 1.0 & $(0.8-1.3)$ \\
\hline $3-4$ & 1.3 & $(1.1-1.5)$ & 1.2 & $(0.8-1.7)$ & 1.2 & $(1.0-1.5)$ & 1.2 & $(0.9-1.4)$ \\
\hline 5-6 (reference) & 1.0 & & 1.0 & & 1.0 & & 1.0 & \\
\hline $7-9$ & 1.0 & $(0.9-1.2)$ & 1.0 & $(0.7-1.4)$ & 0.8 & $(0.6-1.0)$ & 0.9 & $(0.7-1.1)$ \\
\hline 10-13 & 0.9 & $(0.7-1.1)$ & 1.2 & $(0.8-1.7)$ & 0.6 & $(0.5-0.9)$ & 0.7 & $(0.5-1.0)$ \\
\hline $14-17$ & 0.9 & $(0.7-1.1)$ & 1.6 & $(1.1-2.2)$ & 0.5 & $(0.4-0.8)$ & 0.6 & $(0.5-0.9)$ \\
\hline
\end{tabular}

*Age-related change: test for the significance of change in prevalence with age for each of the symptoms, calculated with GEE and presented as odds ratio of change in prevalence per age group with respective p-values, accounting for repeated nature of measurements and clustered data. Baseline group: 5-6-year-old children.

All symptoms refer to the past 12 months.

${ }^{a}$ Frequent wheeze ( $\geq 4$ wheeze attacks in past 12 months)

${ }^{b}$ Wheeze always causing shortness of breath

${ }^{c}$ Sleep disturbed due to wheeze ( $>1 /$ week)

${ }^{\mathrm{d}}$ At least moderate disturbance of daily activities due to wheeze

$\mathrm{OR}$, odds ratio (GEE, generalised estimating equations, analysis) 


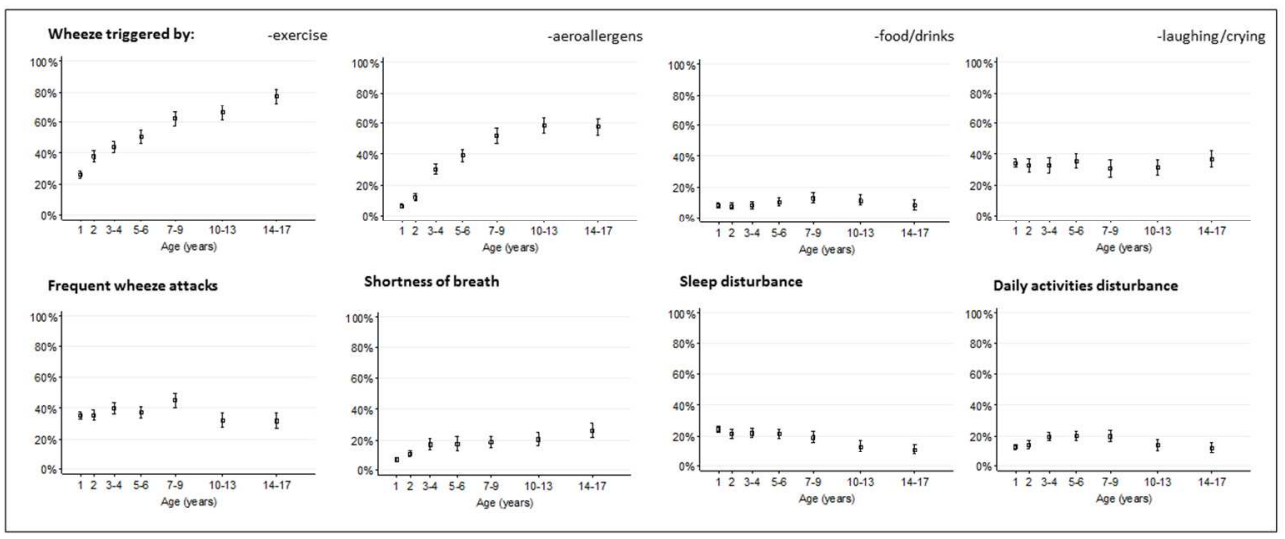

Fig. 3. Relative prevalence of wheeze, triggered by different factors, and of different indicators of wheeze severity among children with current wheeze from age 1 to 17 years. Prevalence presented as proportion (in $\%$ ) with $95 \%$ confidence intervals.

$338 \times 150 \mathrm{~mm}(96 \times 96$ DPI)

John Wiley \& Sons, Inc. 
Table E5-Age-related change in prevalence of wheeze phenotypes (episodic viral and multiple trigger) among children with current wheeze, presented as OR, for different age groups* 
Table E6-Age-related change in prevalence of wheeze with triggers among children with current wheeze, presented as OR, for different age groups*

\begin{tabular}{|c|c|c|c|c|c|c|c|c|}
\hline \multirow[b]{2}{*}{ Age groups (years) } & \multicolumn{2}{|c|}{ Exercise } & \multicolumn{2}{|c|}{ Aeroallergens } & \multicolumn{2}{|c|}{ Food/drinks } & \multicolumn{2}{|c|}{ Laughing/crying } \\
\hline & OR & $(95 \% \mathrm{CI})$ & OR & $(95 \% \mathrm{CI})$ & OR & $(95 \% \mathrm{CI})$ & OR & $(95 \% \mathrm{CI})$ \\
\hline 1 & 0.4 & $(0.3-0.5)$ & 0.1 & $(0.1-0.2)$ & 0.8 & $(0.6-1.1)$ & 1.0 & $(0.8-1.3)$ \\
\hline 2 & 0.6 & $(0.5-0.8)$ & 0.2 & $(0.2-0.3)$ & 0.8 & $(0.5-1.1)$ & 1.0 & $(0.7-1.2)$ \\
\hline $3-4$ & 0.8 & $(0.6-1.0)$ & 0.7 & $(0.6-0.9)$ & 0.8 & $(0.6-1.2)$ & 0.9 & $(0.7-1.2)$ \\
\hline 5-6 (reference) & 1.0 & & 1.0 & & 1.0 & & 1.0 & \\
\hline 7-9 & 1.6 & $(1.3-2.0)$ & 1.7 & $(1.3-2.1)$ & 1.1 & $(0.8-1.7)$ & 0.9 & $(0.7-1.3)$ \\
\hline 10-13 & 2.1 & $(1.6-2.6)$ & 2.3 & $(1.8-2.9)$ & 1.1 & $(0.8-1.7)$ & 0.9 & $(0.7-1.2)$ \\
\hline 14-17 & 3.6 & $(2.7-4.7)$ & 2.4 & $(1.9-3.1)$ & 0.7 & $(0.4-1.1)$ & 1.2 & $(0.9-1.6)$ \\
\hline
\end{tabular}

*Age-related change: test for the significance of change in prevalence with age for each of the symptoms, calculated with GEE and presented as odds ratio of change in prevalence per age group with respective p-values, accounting for repeated nature of measurements and clustered data. Baseline group: 5-6-year-old children. All symptoms refer to the past 12 months.

OR, odds ratio (GEE, generalised estimating equations, analysis) 
Table E7-Age-related change in prevalence of indicators of wheeze severity among children with current wheeze, presented as OR, for different age groups*

\begin{tabular}{|c|c|c|c|c|c|c|c|c|}
\hline \multirow[b]{2}{*}{ Age groups (years) } & \multicolumn{2}{|c|}{ Frequent wheeze $^{\mathrm{a}}$} & \multicolumn{2}{|c|}{ Shortness of breath $^{b}$} & \multicolumn{2}{|c|}{ Sleep disturbance ${ }^{c}$} & \multicolumn{2}{|c|}{ Daily activities disturbance } \\
\hline & OR & $(95 \% \mathrm{CI})$ & OR & $(95 \% \mathrm{CI})$ & OR & $(95 \% \mathrm{CI})$ & OR & $(95 \% \mathrm{CI})$ \\
\hline 1 & 1.0 & $(0.9-1.2)$ & 0.4 & $(0.2-0.5)$ & 1.4 & $(1.1-1.7)$ & 0.7 & $(0.6-0.9)$ \\
\hline 2 & 1.0 & $(0.8-1.2)$ & 0.6 & $(0.4-0.9)$ & 1.1 & $(0.9-1.4)$ & 0.8 & $(0.6-1.0)$ \\
\hline $3-4$ & 1.2 & $(1.0-1.5)$ & 1.0 & $(0.7-1.6)$ & 1.1 & $(0.9-1.5)$ & 1.1 & $(0.8-1.3)$ \\
\hline 5-6 (reference) & 1.0 & & 1.0 & & 1.0 & & 1.0 & \\
\hline $7-9$ & 1.3 & $(1.1-1.7)$ & 1.1 & $(0.7-1.6)$ & 0.9 & $(0.7-1.2)$ & 1.0 & $(0.7-1.3)$ \\
\hline $10-13$ & 0.8 & $(0.6-1.1)$ & 1.2 & $(0.8-1.9)$ & 0.6 & $(0.4-0.9)$ & 0.7 & $(0.5-1.0)$ \\
\hline 14-17 & 0.8 & $(0.6-1.0)$ & 1.7 & $(1.2-2.6)$ & 0.5 & $(0.3-0.7)$ & 0.6 & $(0.4-0.9)$ \\
\hline
\end{tabular}

*Age-related change: test for the significance of change in prevalence with age for each of the symptoms, calculated with GEE and presented as odds ratio of change in prevalence per age group with respective p-values, accounting for repeated nature of measurements and clustered data. Baseline group: 5-6-year-old children.

All symptoms refer to the past 12 months.

${ }^{a}$ Frequent wheeze ( $\geq 4$ wheeze attacks in past 12 months)

${ }^{\mathrm{b}}$ Wheeze always causing shortness of breath

${ }^{\mathrm{c}}$ Sleep disturbed due to wheeze $(>1 /$ week)

${ }^{\mathrm{d}}$ At least moderate disturbance of daily activities due to wheeze

$\mathrm{OR}$, odds ratio (GEE, generalised estimating equations, analysis) 
Table E8-Unweighted and weighted prevalence of wheeze, episodic viral and multiple trigger wheeze, wheeze with different triggers, and indicators of severe wheeze in the entire cohort of children (absolute prevalence)

\begin{tabular}{|c|c|c|c|c|c|c|c|}
\hline Age group & $\begin{array}{l}\text { 1-year-olds } \\
(\mathrm{N}=4,102)\end{array}$ & $\begin{array}{l}\text { 2-year-olds } \\
(\mathrm{N}=3,163)\end{array}$ & $\begin{array}{l}\text { 3-4-year-olds } \\
(\mathrm{N}=4,071)\end{array}$ & $\begin{array}{l}\text { 5-6-year-olds } \\
(\mathrm{N}=4,031)\end{array}$ & $\begin{array}{l}\text { 7-9-year-olds } \\
(\mathrm{N}=3,244)\end{array}$ & $\begin{array}{l}\text { 10-13-year-olds } \\
(\mathrm{N}=2,204)\end{array}$ & $\begin{array}{l}\text { 14-17-year-olds } \\
(\mathrm{N}=2,025)\end{array}$ \\
\hline & $\%(\mathrm{CI})$ & $\%(\mathrm{CI})$ & $\%(\mathrm{CI})$ & $\%(\mathrm{CI})$ & $\%(\mathrm{CI})$ & $\%(\mathrm{CI})$ & $\%(\mathrm{CI})$ \\
\hline Wheeze & $35.8(34.3-37.3)$ & $24.0(22.5-25.5)$ & $20.1(18.9-21.3)$ & $16.9(15.8-18.1)$ & $14.5(13.2-15.7)$ & $16.6(15.0-18.1)$ & $16.7(15.1-18.4)$ \\
\hline Weighted: & $37.1(35.5-38.7)$ & $25.0(23.3-26.6)$ & $20.4(19.0-21.8)$ & $18.2(16.6-19.9)$ & $15.4(13.5-17.4)$ & $16.1(13.9-18.3)$ & $18.5(16.3-20.8)$ \\
\hline Episodic viral wheeze & $23.8(22.5-25.2)$ & $15.8(14.5-17.1)$ & $11.2(10.2-12.2)$ & $9.0(8.1-9.9)$ & $5.4(4.6-6.2)$ & $6.4(5.4-7.5)$ & $6.5(5.3-7.7)$ \\
\hline Weighted: & $24.3(22.9-25.7)$ & $16.1(14.8-17.5)$ & $11.2(10.1-12.3)$ & $9.2(8.1-10.4)$ & $6.0(4.7-7.3)$ & $6.1(4.7-7.5)$ & $7.1(5.5-8.6)$ \\
\hline Multiple trigger wheeze & $11.5(10.5-12.4)$ & 7.6(6.6-8.5) & $8.0(7.2-8.9)$ & $7.5(6.8-8.4)$ & $8.5(7.5-9.5)$ & $9.6(8.4-10.9)$ & $9.7(8.3-11.0)$ \\
\hline Weighted: & $12.2(11.1-13.3)$ & $8.1(7.1-9.2)$ & $8.3(7.3-9.3)$ & $8.5(7.2-9.8)$ & $9.0(7.4-10.5)$ & $9.7(8.0-11.5)$ & $11.1(9.2-13.1)$ \\
\hline \multicolumn{8}{|l|}{ Wheeze, triggered by: } \\
\hline Exercise & $8.6(7.7-9.4)$ & $8.2(7.2-9.2)$ & $7.9(7.0-8.7)$ & $7.8(6.9-8.6)$ & $8.5(7.5-9.4)$ & $11.0(9.7-12.3)$ & $12.9(11.5-14.4)$ \\
\hline Weighted: & $9.4(8.4-10.4)$ & $8.6(7.6-9.7)$ & $8.3(7.3-9.3)$ & $9.2(7.8-10.6)$ & $9.7(8.0-11.5)$ & $11.1(9.2-13.0)$ & $14.7(12.6-16.8)$ \\
\hline Aeroallergens & $2.0(1.6-2.5)$ & $2.5(1.9-3.0)$ & $5.2(4.5-5.9)$ & $6.0(5.3-6.8)$ & $7.0(6.1-7.8)$ & $9.5(8.3-10.8)$ & $9.5(8.2-10.8)$ \\
\hline Weighted: & $2.2(1.7-2.7)$ & $2.7(2.0-3.3)$ & $5.4(4.6-6.2)$ & $7.5(6.1-8.8)$ & 7.5(5.9-9.1) & $9.4(7.6-11.1)$ & $10.6(8.8-12.4)$ \\
\hline Food/drinks & $2.7(2.2-3.2)$ & $1.6(1.2-2.1)$ & $1.3(1.0-1.7)$ & $1.5(1.1-1.9)$ & $1.6(1.2-2.0)$ & $1.7(1.2-2.3)$ & $1.3(0.8-1.8)$ \\
\hline Weighted: & $3.0(2.4-3.6)$ & $1.5(1.0-2.0)$ & $1.6(1.1-2.1)$ & $1.7(1.2-2.2)$ & $1.6(1.1-2.1)$ & $1.8(0.9-2.6)$ & $1.4(0.6-2.2)$ \\
\hline Laughing/crying & $10.3(9.3-11.3)$ & $5.7(4.9-6.6)$ & $3.1(2.6-3.7)$ & $3.7(3.1-4.3)$ & $2.5(2.0-3.1)$ & $4.8(3.9-5.7)$ & $6.0(4.9-7.0)$ \\
\hline Weighted: & $11.1(10.0-12.1)$ & $6.2(5.2-7.2)$ & $3.7(2.9-4.5)$ & $4.7(3.6-5.9)$ & $3.1(2.2-4.0)$ & $5.5(4.0-6.9)$ & $6.3(5.0-7.7)$ \\
\hline Indicators of severe wheeze & & & & & & & \\
\hline Frequent wheeze $^{\mathrm{a}}$ & $12.5(11.5-13.6)$ & $8.4(7.4-9.4)$ & $8.1(7.2-8.9)$ & $6.4(5.6-7.2)$ & $6.6(5.7-7.4)$ & $5.4(4.4-6.3)$ & $5.3(4.3-6.3)$ \\
\hline Weighted: & $13.3(12.2-14.4)$ & $8.8(7.7-9.9)$ & $8.0(7.1-9.0)$ & $7.4(6.1-8.6)$ & $7.0(5.5-8.5)$ & $6.0(4.5-7.4)$ & $6.1(4.6-7.7)$ \\
\hline Shortness of breath ${ }^{\mathrm{b}}$ & $2.4(1.9-2.9)$ & $2.5(1.9-3.0)$ & $3.6(2.8-4.3)$ & $2.9(2.1-3.8)$ & $2.8(2.2-3.4)$ & $3.5(2.7-4.3)$ & $4.5(3.5-5.4)$ \\
\hline Weighted: & $2.5(1.9-3.0)$ & $2.6(2.0-3.2)$ & $3.6(2.7-4.4)$ & $2.9(2.0-3.8)$ & $2.5(1.9-3.2)$ & $3.6(2.5-4.7)$ & $4.7(3.5-6.0)$ \\
\hline Sleep disturbance ${ }^{c}$ & $8.6(7.8-9.5)$ & $5.0(4.3-5.8)$ & $4.4(3.8-5.1)$ & $3.6(3.0-4.2)$ & $2.8(2.2-3.4)$ & $2.2(1.5-2.8)$ & $1.9(1.3-2.5)$ \\
\hline Weighted: & $9.3(8.3-10.2)$ & $5.5(4.7-6.4)$ & $4.8(4.0-5.6)$ & $5.0(3.8-6.2)$ & $3.0(2.0-4.1)$ & $2.5(1.5-3.5)$ & $2.1(1.3-2.9)$ \\
\hline Daily activities disturbance ${ }^{\mathrm{d}}$ & $4.6(4.0-5.3)$ & $3.4(2.8-4.0)$ & $4.0(3.4-4.6)$ & $3.5(3.0-4.1)$ & $3.0(2.4-3.6)$ & $2.3(1.7-3.0)$ & $2.0(1.4-2.6)$ \\
\hline Weighted: & $4.9(4.2-5.7)$ & $3.8(3.1-4.6)$ & $4.2(3.5-4.9)$ & $4.5(3.4-5.5)$ & $3.0(2.0-4.0)$ & $3.2(1.9-4.4)$ & $2.7(1.7-3.7)$ \\
\hline
\end{tabular}


Table E9-Unweighted and weighted prevalence of wheeze, episodic viral and multiple trigger wheeze, wheeze with different triggers, and indicators of severe wheeze among children with any current wheeze (relative prevalence)

\begin{tabular}{|c|c|c|c|c|c|c|c|}
\hline Age group & $\begin{array}{l}\text { 1-year-olds } \\
\left(\mathrm{N}_{\mathrm{cw}}=1447\right) \\
\end{array}$ & $\begin{array}{l}\text { 2-year-olds } \\
\left(N_{c w}=744\right)\end{array}$ & $\begin{array}{l}\text { 3-4-year-olds } \\
\left(N_{\mathrm{cw}}=810\right)\end{array}$ & $\begin{array}{l}\text { 5-6-year-olds } \\
\left(N_{\mathrm{cw}}=675\right)\end{array}$ & $\begin{array}{l}\text { 7-9-year-olds } \\
\left(N_{\mathrm{cw}}=465\right)\end{array}$ & $\begin{array}{l}\text { 10-13-year-olds } \\
\left(N_{\mathrm{cw}}=362\right)\end{array}$ & $\begin{array}{l}\text { 14-17-year-olds } \\
\left(N_{c w}=336\right)\end{array}$ \\
\hline & $\%(\mathrm{CI})$ & $\%(\mathrm{CI})$ & $\%(\mathrm{CI})$ & $\%(\mathrm{CI})$ & $\%(\mathrm{CI})$ & $\%(\mathrm{CI})$ & $\%(\mathrm{CI})$ \\
\hline Episodic viral wheeze & $67.5(65.1-70.0)$ & $67.6(64.2-71.0)$ & $58.2(54.7-61.7)$ & $54.4(50.5-58.2)$ & $38.7(34.2-43.2)$ & $40.1(34.9-45.2)$ & $40.0(34.5-45.5)$ \\
\hline Weighted: & $66.6(63.9-69.1)$ & $66.5(62.7-70.1)$ & $57.5(53.5-61.4)$ & $52.1(46.9-57.3)$ & $40.0(33.0-46.9)$ & $38.5(31.2-45.7)$ & $38.9(31.8-45.9)$ \\
\hline Multiple trigger wheeze & $32.5(30.0-34.9)$ & $32.4(29.0-35.8)$ & $41.8(38.3-45.3)$ & $45.6(41.8-49.5)$ & $60.9(56.3-65.4)$ & $59.9(54.8-65.1)$ & $60.0(54.5-65.5)$ \\
\hline Weighted: & $33.4(30.9-36.1)$ & $33.5(29.9-37.3)$ & $42.5(38.5-46.4)$ & $47.9(42.7-53.0)$ & $59.7(52.7-66.7)$ & $61.5(54.3-68.8)$ & $61.1(54.1-68.2)$ \\
\hline Wheeze, triggered by: & & & & & & & \\
\hline Exercise & $25.9(23.5-28.3)$ & $37.6(33.8-41.3)$ & $43.8(40.2-47.7)$ & $50.4(46.4-54.4)$ & $62.1(57.5-66.7)$ & $66.5(61.6-71.4)$ & $77.5(73.0-82.0)$ \\
\hline Weighted: & $27.5(24.9-30.1)$ & $38.0(34.1-41.9)$ & $45.2(41.0-49.3)$ & $54.6(49.3-59.9)$ & $66.0(59.7-72.2)$ & $69.0(62.4-75.7)$ & $79.0(73.6-84.5)$ \\
\hline Aeroallergens & $6.2(4.9-7.6)$ & $11.8(9.3-14.3)$ & $30.2(26.7-33.7)$ & $39.0(35.1-42.9)$ & $51.8(49.1-58.9)$ & $58.4(53.2-63.6)$ & $57.7(52.3-63.0)$ \\
\hline Weighted: & $6.7(5.2-8.2)$ & $12.1(9.4-14.8)$ & $30.7(26.8-34.6)$ & $44.4(38.9-50.0)$ & $51.7(44.4-59.0)$ & $59.0(51.7-66.2)$ & $57.7(50.7-64.7)$ \\
\hline Food/drinks & $8.2(6.7-9.7)$ & 7.7(5.6-9.7) & $8.0(5.9-10.1)$ & $10.2(7.7-12.7)$ & $12.6(9.4-15.9)$ & $11.1(7.8-14.5)$ & $8.1(5.1-11.1)$ \\
\hline Weighted: & $8.9(7.2-10.6)$ & $6.9(4.8-9.1)$ & $9.3(6.5-12.0)$ & $10.6(7.5-13.8)$ & $12.3(8.4-16.1)$ & $12.0(6.7-17.3)$ & $8.0(3.8-12.2)$ \\
\hline Laughing/crying & $34.0(31.3-36.8)$ & $32.5(28.4-36.6)$ & $32.6(27.6-37.5)$ & $35.4(30.6-40.2)$ & $30.4(24.7-36.1)$ & $30.8(25.8-35.8)$ & $36.6(31.4-41.9)$ \\
\hline Weighted: & $35.3(32.4-38.2)$ & $33.2(28.8-37.6)$ & $34.8(28.8-40.7)$ & $39.7(32.4-47.0)$ & $34.9(26.8-43.0)$ & $36.6(29.0-44.2)$ & $35.1(28.5-41.6)$ \\
\hline Indicators of severe wheeze & & & & & & & \\
\hline Frequent wheeze $^{\mathrm{a}}$ & $35.1(32.6-37.6)$ & $35.4(31.9-38.9)$ & $39.8(36.4-43.1)$ & $37.2(33.6-40.9)$ & $45.0(40.5-49.6)$ & $32.1(27.3-37.0)$ & $31.6(26.6-36.6)$ \\
\hline Weighted: & $35.9(33.3-38.5)$ & $35.7(32.0-39.3)$ & $38.7(35.0-42.5)$ & $40.0(34.7-45.1)$ & $44.7(37.7-51.6)$ & $36.3(29.2-43.5)$ & $33.0(26.1-39.9)$ \\
\hline Shortness of breath ${ }^{b}$ & $6.7(5.4-8.0)$ & $10.4(8.2-12.6)$ & $17.2(13.7-20.8)$ & $17.4(12.9-21.9)$ & $18.6(15.0-22.3)$ & $20.5(16.3-24.7)$ & $25.9(21.2-30.7)$ \\
\hline Weighted: & $6.7(5.3-8.0)$ & $10.4(8.1-12.8)$ & 17.1(13.4-20.8) & $17.1(12.1-22.1)$ & $15.9(11.7-20.1)$ & $21.7(15.7-27.7)$ & $24.9(19.0-30.8)$ \\
\hline Sleep disturbance ${ }^{\mathrm{c}}$ & $24.3(22.1-26.6)$ & 21.1(18.2-25.6) & $21.8(19.0-24.7)$ & $21.1(18.0-24.3)$ & $19.0(15.4-22.6)$ & $13.0(9.5-16.5)$ & $10.9(7.5-14.2)$ \\
\hline Weighted: & $25.2(22.8-27.6)$ & $22.4(19.2-25.8)$ & 23.1(19.7-26.5) & $27.2(21.9-32.6)$ & $19.5(13.6-25.4)$ & $15.3(9.8-20.9)$ & $11.1(7.2-15.0)$ \\
\hline Daily activities disturbance ${ }^{\mathrm{d}}$ & $12.9(11.2-14.7)$ & $14.2(11.7-16.8)$ & $19.5(16.7-22.3)$ & $19.9(16.8-22.9)$ & $19.7(16.1-23.3)$ & $13.9(10.3-17.5)$ & $12.0(8.4-15.5)$ \\
\hline Weighted: & $13.4(11.5-15.3)$ & $15.4(12.7-18.2)$ & 20.1(16.9-23.3) & $23.8(18.9-28.7)$ & $18.6(13.0-24.2)$ & $19.0(12.2-25.7)$ & $14.4(9.5-19.3)$ \\
\hline
\end{tabular}


Table E10 - Comparison of parent-reported to self-reported symptoms:

Sensitivity analysis in the 2010 survey $(1,821$ children aged $14-17$ years) in entire cohort

\begin{tabular}{|c|c|c|c|}
\hline Symptom & Parent-reported $(\mathrm{n}=749)$ & Self-reported $(\mathrm{n}=1,072)$ & \\
\hline & $\%(\mathrm{CI})$ & $\%(\mathrm{CI})$ & p-value ${ }^{a}$ \\
\hline Wheeze & $12.3(9.8-15.4)$ & $17.3(14.9-20.0)$ & 0.012 \\
\hline Episodic viral wheeze & $5.2(3.6-7.4)$ & $6.2(4.8-8.1)$ & 0.415 \\
\hline Multiple trigger wheeze & $6.1(4.3-8.5)$ & $10.6(8.6-12.9)$ & 0.005 \\
\hline \multicolumn{4}{|l|}{ Wheeze, triggered by: } \\
\hline Exercise & $8.0(6.0-10.7)$ & $14.4(12.2-16.9)$ & $<0.001$ \\
\hline Aeroallergens & $8.0(6.0-10.7)$ & $8.9(7.2-11.0)$ & 0.570 \\
\hline Food/drinks & $0.9(0.4-2.2)$ & $1.5(0.9-2.5)$ & 0.375 \\
\hline Laughing/crying & $2.2(1.3-3.9)$ & $7.6(6.0-9.6)$ & $<0.001$ \\
\hline \multicolumn{4}{|l|}{ Indicators of severe wheeze } \\
\hline Frequent wheeze ${ }^{\mathrm{b}}$ & $4.0(2.6-6.0)$ & $4.8(3.6-6.5)$ & 0.437 \\
\hline Shortness of breath ${ }^{c}$ & $3.5(2.2-5.5)$ & $4.1(2.9-5.6)$ & 0.617 \\
\hline Sleep disturbance ${ }^{\mathrm{d}}$ & $1.5(0.8-3.0)$ & $1.8(1.1-3.0)$ & 0.651 \\
\hline Daily activities disturbance $^{\mathrm{e}}$ & $1.9(1.0-3.5)$ & $2.0(1.2-3.2)$ & 0.924 \\
\hline
\end{tabular}

${ }^{a}$ Difference between parent- and self-reported symptoms calculated with unpaired (two-sample) t-test

Frequent wheeze ( $>4$ wheeze attacks in past 12 months)

Wheeze always causing shortness of breath

${ }^{\mathrm{d}}$ Sleep disturbed due to wheeze $(>1 /$ week $)$

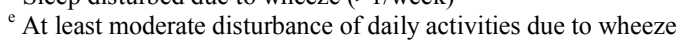

All wheezing characteristics refer to the past 12 months. 
Fig. 1. Absolute prevalence of wheeze, triggered by different factors, and of different indicators of wheeze severity in entire cohort of children from age 1 to 17 years. Prevalence presented as proportion (in \%) with $95 \%$ confidence intervals.

Fig. 2. Prevalence of episodic viral wheeze and of multiple trigger wheeze in the entire cohort (absolute prevalence) and among children with current wheeze (relative prevalence, from age 1 to 17 years. Prevalence is presented as proportion (in \%) with 95\% confidence intervals.

Fig. 3. Relative prevalence of wheeze, triggered by different factors, and of different indicators of wheeze severity among children with current wheeze from age 1 to 17 years. Prevalence presented as proportion (in \%) with $95 \%$ confidence intervals.

Fig. E1. Age of the children of the Leicester Respiratory Cohorts participating in the respective surveys; The bands on the $\mathrm{x}$-axis show the seven age groups used for the analysis (1, 2, 3-4, 5-6, 7-9, 10-13, and 14-17 year-olds). The y-axis shows the years when surveys were conducted. In 1999, only those who responded in 1998 and were born in years 1996-7 (age 1 at the first survey) were included.

John Wiley \& Sons, Inc. 